\title{
SISTEM PENGOLAHAN KONTRAK KREDIT PADA PT. FEDERAL INTERNATIONAL FINANCE (FIFGROUP) MATARAM
}

\author{
Aris Ariawatan ${ }^{1}$, Agus Marjan Saputra $^{2}$ \\ ASM Mataram ${ }^{1,2}$ \\ poetra.um1607@gmail.com
}

\begin{abstract}
Abstrak - Judul dari penelitian ini adalah Sistem pengolahan kontrak kredit pada PT. Federal International Finance (FIFGROUP) Mataram. Penelitian ini bertujuan untuk mengetahui bagaimana sistem pengolahan kontrak kredit pada PT. Federal International Finance (FIFGROUP) Mataram. Penelitian ini bermanfaat, sebagai bahan masukan pengembangan bagi perusahaan FIFGROUP Mataram dalam menentukan langkah- langkah kebijakan yang akan dating terkait dengan sistem pengelolaan kontrak kredit. Jenis penelitian yang digunakan dalam penelitian ini yaitu jenis penelitian Deskriftif. Adapun teknik pengumpulan data dari penelitian ini berupa teknik wawancara, observai dan dokumentas. Jenis data yang digunakan adalah data kuantitatif dan data kualitatif serta sumber data dari penelitian berupa data primer dan data sekunder. Hasil penelitian menunjukkan bahwa pengolahan kontrak kredit pada PT. Federal International Finance (FIFGROUP) Mataram. Dapat di proses atau dikerjakan melalui beberapa bagian yang berintraksi dan bekerjasam melakukan pengolahan kontrak kredit.
\end{abstract}

Kata kunci : Sistem, Pengolahan, dan Kontrak Kredit

\section{Pendahuluan}

PT. Federal International Financa (FIFGROUP) merupakan perusahaan atau lembaga keuangan yang bergerak di bidang pembiayaan (leasing) dengan nama merk sebagai berikut : FIFASTRA adalah jasa layanan pembiayaan sepeda motor Honda, baik motor baru maupun second yang berkualitas. SPEKTRA adalah jasa layanan pembiayaan multiproduk mulai dari elektronik sampai dengan perabot rumah tangga.

Salah satu bagian terpenting yang perlu diperhatikan dalam melakukan kontrak perjanjian kredit di PT. Federal International Finance (FIFGROUP) adalah memenuhi persyaratanpersyaratan yang tertulis didalam kontrak, seperti dokumen kontrak kredit dan lain- lain.

Dokumen kontrak kredit merupakan sarana untuk menyampaikan pernyataan atau informasi secara tertulis dari pihak kreditur kepada pihak debitur. Informasi yang terkandung dari dalam dokumen dkontrak kredit dapat berupa pemberitahuan, permohonan, pernyataan, permintaan, laporan perjanjian, persetujuan dan sebagainya.

Dokumen kontrak kredit sebagai bahan pengingat serta sebagai dokumentasi perusahaan. Melihat begitu pentingnya dokumen kontrak kredit, maka proses manajemen seperti penyimpanan dan pencarian dari dokumen kontrak kredit tersebut harus perlu diperhatikan. Dalam pencarian dokumen kontrak kredit, apabila dokumen kontrak kredit tersebut memiliki nomor kontrak yang dapat dicari, maka proses untuk pencarian dokumen kontrak tersebut akan berlangsung secara cepat, sehingga waktu yang dibutuhkan untuk pencarian dokumen kontrak kredit tersebut tidak akan terbuang. Dokumen kontrak kredit juga berperan sebagai bahan pengingat dan sebagai bahan dokumentasi.

Dari besarnya pertumbuhan dokumen kontrak kredit yang dihasilkan dari proses administrasi akan menyebabkan terjadinya penumpukan dan menimbulkan masalah yang besar, seperti meningkatnya kebutuhan akan ruangan penyimpanan dokumen kontrak kredit serta kesulitan untuk dapat menemukan kembali dokumen kontrak kredit apabila dibutuhkan. Oleh sebab itu, usaha- usaha untuk mengantisipasi masalah tersebut setidaknya kita harus mempersiapkan antara lain, penataan dokumen kontrak kredit secara baik dan benar. Pengolahan kontrak kredit dilakukan perusahaan yang melibatkan bagian administrasi dan departemen kredit. Bagian administrasi memberikan kontrak kredit yang sudah disetujui atau yang sudah disahkan oleh kreditur dengan 
debitur dan bagian hard copy menangani atau mengolah kontrak kredit yang diberikan oleh bagian administrasi

\section{Metode Pengumpulan Data}

\section{Metode Pengumpulan Data}

1. Jenis Penelitian

Adapun jenis penelitian yang digunakan untuk menyusun laporan ini yaitu penelitian deskriptif, yaitu sebagai sebuah penelitian yang dilakukan untuk melukiskan variabel demi variable, satu demi satu, dengan mengumpulkan data secara univarian, yang digunakan untuk mencari teoriteori tentative, bukan menguji teori (Rakhmat, 2005: 25).

\section{Teknik Pengumpulan Data}

Adapun teknik dalam pengumpulan data yang dilakukan dalam menyusun laporan karya Tugas Akhir (KTA) ini yaitu :

\section{a. Wawancara}

Wawancara, yaitu pengumpulan data dengan mengajukan pertanyaan- pertanyaan secara bebas baik terstruktur maupun tidak terstruktur dengan tujuan untuk memperoleh informasi secara luas mengenai obyek penelitian (Sunyoto, 2013: 22).

\section{b. Dokumentasi}

Dokumentasi, yaitu dokumen yang berkenan dengan peristiwa atau momen atau kegiatan, yang telah lalu, yang padanya mungkin dihasilkan sebuah informasi, fakta dan data yang diinginkan dalam penelitian (Ibrahim, 2015: 93).

\section{c. Observasi}

Observasi, yaitu penelitian dengan cara pengamatan langsung terhadap kegiatan yang dilaksanakan perusahaan (Sunyoto, 2013: 22).

\section{Landasan Teori}

- Pengertian Sistem

Secara umum pengertian sistem yaitu suatu kesatuan yang terdiri dari dua atau lebih komponen atau subsistem yang berintraksi untuk mencapai suatu tujuan (Rochaety, 2013: 3).

Adapun definisi sistem menurut beberapa ahli antara lain:

1. Menurut Ludwig menyatakan : Sistem adalah seprangkat unsur yang saling berhubungan dan saling mempengaruhi dalam satu lingkungan tertentu.

2. Menurut A. Rapoport menyatakn

: Sistem adalah sekumpulan elemen yang saling berhubungan untuk mencapai suatu tujuan.

3. Menurut L. Ackof menyatakan : Sistem adalah setiap kesatuan secara konseptual atau fisik yang terdiri dari bagian-bagian yang saling mempengaruhi.

Dari beberapa pengertian sistem yang di uraikan oleh para ahli, maka dapat kita simpulkan bahwa sistem adalah sekumpulan unsur, komponen, elemen- eleme yang masingmasing bagiannya beroperasi atau bekerjasama untuk mencapai sustu tujuan tertentu.

Pengertian pengolahan

Pengolahan adalah sebuah proses mengusahakan atau mengerjakan sesuatu (barang dsb) supaya menjadi lebih sempurna." (Tim Penyusun Kamus Pusat Pembinaan dan Pengembangan Bahasa: 1988).

\section{Pengertian Kontrak}

Sebagaimana yang dijelaskan oleh Abdul Ghofur Anshori dalam bukunya berjudul PokokPokok hukum perjanjian islam di indonesia, kontrak (contrac atau overeenkomst) adalah suatu perbuatan dengan mana satu pihak atau lebih mengikatkan dirinya terhadap satu orang atau lebih dan di indonesia di ataur dalam pasal

1313 KUH Perdata.

Pengertian Kredit

Kredit adalah suatu pemberian prestasi oleh suatu pihak kepada pihak lain dan prestasi itu akan dikembalikan lagi pada suatu masa tertentu yang akan datang disertai dengan suatu kontra prestasi berupa bunga" (Drs. Muchdarsyah Sinungan).

\section{Pengertian kontrak kredit}

Kontrak atau perjanjian yang dibuat antara pemberi fasilitas dengan penerima fasilitas, dalam hal ini pemberi fasilitas menyediakan dana untuk membeli barang dari penjual barang, untuk digunakan oleh sipenerima pfasilitas, dan penerima fasilitas berkewajiban untuk membayar 
pinjaman itu, baik berupa pokok dan barang, sesuai dengan jangka waktu yang telah ditentukan oleh kedua belah pihak (Salim, 2015:47).

\section{Pembahasan}

Sistem pengolahan kontrak Merupakan proses mengerjakan penanganan kontrak kredit yang dilakukan secara tersetruktur, dimana terdiri dari elemen-elemen, bagian-bagian atau unsur yang berkaiatan dan berintraksi dalam melakukan pengolahan kontrak kredit yaitu sebagai berikut:

1. Konsumen

Konsumen merupakan pihak yang akan melakukan suatu kredit, dimana seorang konsumen pertama kali datang ke sebuah prusahaan dealer merek motor honda. Dealer merupakan sebuah perusahaan yang menyediakan barang berbagai macam motor merek honda.

2. Salesman

Salesman merupakan pihak yang melakukan promosi dan menangani konsumen yang akan melakukan kredit barang seperti motor merk honda. Adapun tugas seorang sales dalam menangani konsumen yaitu memotivasi, mengarahkan dan meyakinkan calon pelanggan untuk melakukan kredit barang.

3. Departemen kredit

Departemen kredit merupakan salah satu bagian dari perusahaan FIFGROUP Mataram yang bertugas menangani informasi yang diberikan oleh salesman mengenai data calon konsumen yang ingin melakukan kredit barang motor merk honda.

Departemen kredik akan menginput data calon pelanggan yang akan melakukan kredit barang kedalam sistem komputer sebelum dilakukannya survey kelayakan kredit.

4. Surveyer

Surveyer adalah bagian dari perusahaan FIFGROUP yang bertugas untuk melakukan survey calon pelanggan untuk memastikan apakah layak atau tidak untuk melakukan kredit barang. Jika calon pelanggan dinyatakan layak untuk melakukan kredit, maka data hasil survey akan dikembalikan ke departemen kredit untuk di input dan dikirim ke FIFGROUP pusat yang berada di jakarta.

5. Dealer

Dealer adalah perusahaan penyedia barang yang sebelumnya telah melakukan kerjasama dengan perusahaan FIFGROUP dalam penyediaan kredit motor merk honda. Dealer bertugas mengeluarkan barang yang akan dikredit oleh konsumen, akan tetapi sebelum barang dikeluarkan, FIFGROUP terlebih dahulu harus melakukan pembayaran secara cas kepada dealer.

\section{Hard Copy}

Hard Copy adalaha bagian yang menangani kontrak kredit pelanggan yang sudah dinyatakan resmi melakukan kredit barang. Hard copy bertugas untuk mencetak kontrak kredit yang kemudian diserahkan kepada konsumen dan collector yang berfungsi sebagai tanda atau bukti seorang konsumen telah melakukan kredit dalam jangka waktu tertentu.

\section{Collector}

Collector adalah bagian yang melakukan penagihan kepada konsumen yang telat dalam melakukan pembayaran angsuran sesuai dengan jangka waktu pembayaran yang sudah di tentukan oleh perusahaan FIFGROUP.

Dalam sistem pengolahan kontrak kredit pada PT. Federal International Finance (FIFGROUP) Mataram terdapat serangkaian kegiatan yang harus dilaksanakan secara teratur dan bertahap yaitu sebagai berikut:

1. Menerima kontrak

2. Memeriksa kontrak

3. Cetak kontrak

4. Pilah kontrak

5. Penyimpanan/Filling kontrak

\section{Kesimpulan}

Berdasarkan uraian pembahasan di bab IV, maka penulis dapat menarik kesimpulan yaitu :

1. Sistem pengolahan kontrak kredit pada PT Federal International Finance (FIFGROUP) merupakan salah satu kegiatan mengerjakan suatu kontrak agar lebih sempurna dan berguna sehingga dapat memperlancar pencapain tujuan dari perusahaan khususnya PT. FIFGROUP Mataram.

2. Elemen-elemen dalam sistem pengolahan kontrak kredit pada PT. FIFGROUP adalah konsumen, salesmen, departemen kredit, surveyer, dealer, hard copy dan collector.

3. Serangkaian kegiatan sistem dalam pengolahan kontrak kredit pada FIFGROUP adalah menerima kontrak, memeriksa kontrak, cetak kontrak, pilah kontrak dan penyimpanan/ filling kontrak. 


\section{Daftar Pustaka}

Elshabrina. 2013. Kumpulan Surat Kontrak. Pendirian Usaha Paling Dicari, Cemerlang Publishing.

HS, Salim. 2015. Hukum Kontrak Perjanjian, Pinjaman dan Hibah. Jakarta: Sinar Grafika.

Ibrahim. 2015. Metode Peneltian Kualitatif. Bandung : Alfabeta.

Juliana, I Nengah. 2014. Kontrak Manajemen Hotel Jaringan Internasional. PT. Bandung: Citra Aditya Bakti.

Purwanto. 2017. Metode Penelitian Kuantitatif Untuk Administrasi Publik dan Masalah- Masalah Sosial Edisi Kedua. Yogyakarta:Gava Media. Yaroli Weni. 2014. Dalam KTA ,Tugas Akhir. Mataram.

Rochaety Eti. 2013. Z Ridwan, Faizal. Setyowati Tupi. Sistem Informasi Manajemen. Edisi 2. Jakarta: Mitra Wacana media. 